\title{
Impact of recipient marrow stromal cells functional characteristics on engraftment after allo-HSCT
}

\author{
Ildar M. Barkhatov, Nikolay Yu Tsvetkov, Daniil E. Ershov, Marina Y. Lavrukhina, Alena I. Shakirova, Alisa Ya. Potter, \\ Anna G. Smirnova, Ludmila S. Zubarovskaya, Boris V. Afanasyev \\ R. M. Gorbacheva Memorial Research Institute of Children Oncology, Hematology and Transplantation, and Chair of Hema- \\ tology, Transfusiology and Transplantation, The First St. Petersburg State I. Pavlov Medical University, St. Petersburg, Russian \\ Federation
}

Dr. Ildar M.Barkhatov, PhD, Laboratory Head, R. M. Gorbacheva Memorial Research Institute of Children Oncology, Hematology and Transplantation, The First St. Petersburg State I. Pavlov Medical University, L.Tolstoy St. 6/8, 197022, St. Petersburg, Russian Federation
Phone: $+7(911) 7782785$

E-mail: i.barkhatov@gmail.com

\section{Summary}

Functional insufficiency of stem cell grafts is not rare in hematopoietic stem cell transplantation (HSCT), thus requiring further development of functional tests for recipient's stromal cells, in order to substantiate clinical indications for co-transplantation of hematopoietic and stromal bone marrow cells. The aim of this study was to investigate a role of bone marrow stromal cells (BMSC) in the donor bone marrow engraftment, and their importance for development of complications after HSCT. Functional analysis of BMSC cultures from thirty-eight recipients of allogeneic hematopoietic stem cells has been shown that induced osteogenic differentiation correlated with faster hematopoiesis recovery in transplanted patients. Moreover, a pronounced ability for adipogenic differentiation proved to be associated with lower probability of the graft hypofunction. A pronounced hemostimulatory activity of stromal cells was observed in our study, thus suggesting effects of short-range hematopoietic growth factors from BMSC upon hematopoietic reconstitution. At the same time, a more pronounced pre-transplant expression of molecules which promote donor HSC homing by the recipient stromal cells was associated with faster hematopoietic recovery after transplantation.

\section{Keywords}

Bone marrow stromal cells, acute leukemia, functional characteristics, differentiation patterns.

\section{Introduction}

Morphological and functional patterns of malignant cells are largely determined by specific somatic gene aberrations, which represent the major factor in biology of oncohematological disorders. Meanwhile, some data suggest expression of tumor markers in non-hematopoietic bone marrow cells from the stromal microenvironment $[2,6]$. Hence, potential mechanisms of leukemogenesis, like as specific gene mutations, may include certain effects of cellular environment which may promote proliferation and development of hematopoietic stem cells $[7,16]$. The so-called bone marrow niches are represented by endothelium, stromal cells, macrophages etc. The role of bone marrow stromal cells (BMSC) in hematopoietic regulation was first described by A.Ya Friedenstein fifty years ago. There are several types of stromal cells, in particular, mesenchymal stem cells (MSC) which are best studied for their potential clinical applications. MSCs are shown to suppress immune conflicts in allogeneic transplantation [10]; to replace and restore functions of the damaged non-hematopoietic tissues [14], support hematopoiesis when co-transplanted with hematopoietic stem cells (HSCs) [11]. These effects are based on favorable actions upon proliferation and differentiation of different hematopoietic lineages, e.g., myeloid and lymphoid progenitors. Hence, studies of stromal cells seem to be quite rational in view of their possible involvement into pathogenesis of oncohematological disorders.

It is known that, despite successful engraftment of donor-derived hematopoietic stem cells after allogeneic stem cell transplantation (alloSCT), the mesenchymal stem cells, are, in general, of host origin, even years post-transplant [15]. 
Some patients after alloSCT do not recover their stem cells despite receiving large amounts of CD34+ blood progenitors. Possible basis for the graft failure may be due to affection of hematopoietic niche by conditioning chemotherapy which could disturb its supportive (nursing) capacity. A number of researchers have identified the cells of osteoblast lineage to be a key cellular component of the HSC niche. These cells are responsible for bone formation $[4,19]$. In addition, some transplant-associated factors might affect the osteoblasts, along with direct driving of hematopoiesis. Thus, it may be assumed that a difference in morphology and functional activity of the bone marrow stromal populations before the transplant could sufficiently influence engraftment kinetics of the donor hematopoietic cells.

The aim of this study was to investigate changes in functional characteristics of bone marrow stromal cells (BMSC) in the patients with pre-treated hematological diseases and evaluate their significance in the post-transplant reconstitution of hematopoiesis.

\section{Materials and Methods}

We have studied bone marrow samples from thirty-eight patients with acute leukemia ( 0 to 47 years old). Twenty healthy donors (13 to 52 years old) served as control group. Bone marrow was obtained by sternal punctures. Separation of mononuclear cells was performed by Ficoll density gradient $(1,077 \mathrm{~g} / \mathrm{l})$ followed by explantation to culture flasks containing alpha-MEM (Biolot, Russia) supplemented with $20 \%$ of fetal calf serum and antibiotics (Penicillin, $100 \mathrm{U} / \mathrm{ml}$, and Streptomycin, $100 \mathrm{U} / \mathrm{ml}$, Gibco). Cell cultures were maintained in sterile closed dishes at $37^{\circ} \mathrm{C}, 100 \%$ humidity and $5 \% \mathrm{CO}_{2}$. All the culture variants were studied in duplicate. To evaluate proliferative characteristics of BMSC, we have counted fibroblastic colony-forming units (CFU-F). After 10 days of culture, the cell colonies were fixed with $96 \%$ ethanol for $30 \mathrm{~min}$, stained by Romanovsky-Giemsa (1:10 dilution) for another $30 \mathrm{~min}$. The fibroblastic colonies were classified into large ( $>20$ cells) and small ones ( $<20$ cells).

To induce osteogenic and adipogenic differentiation of BMSCs, a standard conditioning medium was discarded at days 7 to 10 of primary cultures, and adherent cells were supplemented with fresh culture medium, or with the same medium supplied with differentiation-inducing agents. Osteogenic differentiation was achieved by addition of-glycerophosphate $\left(7 \times 10^{-3} \mathrm{M}\right)$; dexamethasone $\left(1 \times 10^{-8} \mathrm{M}\right)$; ascorbic acid $\left(2 \times 10^{-4} \mathrm{M}\right)$ (Sigma, St Louis, MO, USA). Adipogenic differentiation of the BMSC was induced by dexamethasone $\left(1 \times 10^{-7} \mathrm{M}\right)$; insulin $\left(1 \times 10^{-9} \mathrm{M}\right)$. To detect osteocytic differentiation, the adherent cell layer was stained according to von Kossa method, or with Alizarin Red stain (Sigma, St Louis, MO, USA). Osteocytes were identified by typical calcium inclusions (black or red colour, respectively). To visualize adipocytic differentiation in cultured cell populations, the adherent fraction was fixed with formol vapor for $10 \mathrm{~min}$., and incubated in the working Sudan Red O solution (Sigma-Aldrich, St Louis, MO, USA) for 1 hour at room temperature. Adipocytes were identified by orange lipid inclusions.
In vitro hematopoietic support produced by BMSCs was evaluated in agar drop liquid culture system [1]. A monolayer of adherent marrow cells was used as a source of colony-stimulating factors. Bone marrow mononuclears from healthy donors were used as target cells. The cell colonies (CFU-GM) were counted at day 7 of culture. Colony-forming activity (CFA) and cluster-forming ability (ClFA) was assessed by colony numbers per culture and their sizes, i.e., small colonies, 20 to 40 cells; medium colonies, $41-100$ cells; large colonies, $>100$ cells. Big cell clusters contained 10 to 19 cells; small clusters, 5-9 cells.

In parallel to the mentioned test system, hemostimulating activity of BMSC co-cultured with bone marrow mononuclears was tested in a liquid phase. The average term of coculture was 10-12 days. In order to analyze differentiation potential of hematopoietic progenitors, the colony-forming assays were performed in $100 \mu \mathrm{L}$ Iscove's modified Dulbecco's medium (IMDM) plus $2 \%$ fetal bovine serum (Biolot, Russia), then added to $1 \mathrm{~mL}$ methylcellulose medium containing a cocktail of recombinant human stem cell factor, granulocyte-macrophage colony-stimulating factor, interleukin-3, (MethoCult H4534, Stem Cell Technologies) before and after the co-culture initiation. The cells plated in $35-\mathrm{mm}$ Petri dishes were cultured in a fully humidified environment with $5 \% \mathrm{CO}_{2}$ at $37^{\circ} \mathrm{C}$ for 14 days.

Moreover, we measured expression of several genes responsible for cell adherence (SELECTIN, CXCR4, VCAM and PECAM). To this purpose, we performed reverse transcription of mRNAs from cell lysates. Real-time PCR with gene-specific primers was carried out in a standard reaction mix (Syntol, Russia). The post-PCR amplicon amounts were evaluated by means of a DNA-binding SYBR Green dye. The relative gene expression was normalized for a reference $\mathrm{ABL}$ gene.

Statistical evaluation was performed with STATISTICA software, version 6.0. In cases of statistically significant differences, we performed pairwise comparisons of the series using non-parametric Mann-Whitney criterion for two independent samples. The correlation quotients (r) were calculated using Spearman criterion. Statistical significance between experimental series was proven at confidence levels of $\mathrm{p}<0.05$.

\section{Results and Discussion}

\section{Comparison of BMSCs functional characteristics in patients and healthy donors}

A comparative assessment of fibroblast colony-forming units (CFU-F) CM in healthy donors and patients with acute leukemia shows a significant increase in big fibroblastic colonies of AML and ALL patients ( $\mathrm{p}<0.05$ ). (Fig. 1) These changes in proliferative ability of recipient stromal cells may occur due to the influence of malignant cell clones [18], or by previous rounds of chemotherapy [17]. One should discern between these potential causal factors. 
Meanwhile, the number of CFU-F capable for adipogenic and osteogenic differentiation in acute leukemia was also significantly higher ( $\mathrm{p}<0.05$ ) (Fig. 2). A typical fibroblastic CFU is shown in Fig. 3. These results are in accordance with data presented by Borojevic et al., who showed similar changes of osteogenic marker expression and alkaline phosphatase activity in stromal cells from MDS patients [3]. Moreover, we find higher numbers of adipogenic progenitors in stroma from leukemia patients (AML and ALL), thus, probably, exerting a negative impact upon normal hematopoiesis. These data were recently described also by Le et al. [9].

When testing hemostimulating activity of stromal cells in soft agar, we observed a significant increase in hematopoiesis-supportive ability by stromal cells in acute myeloid leukemia (AML) ( $\mathrm{p}<0.05)$, compared with healthy donors, whereas BMSC in patients with acute lymphoblastic leukemia, did not show similar properties (Fig. 4). This finding may suggest a possible role of stromal microenvironment in supporting malignant cell clones, as described elsewhere [13].

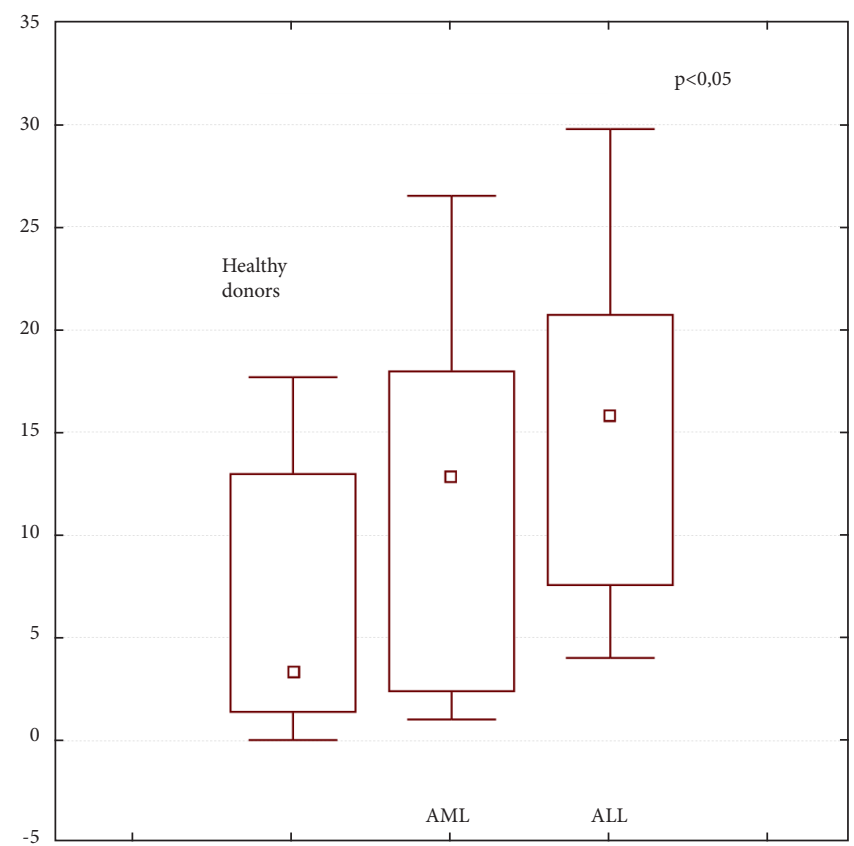

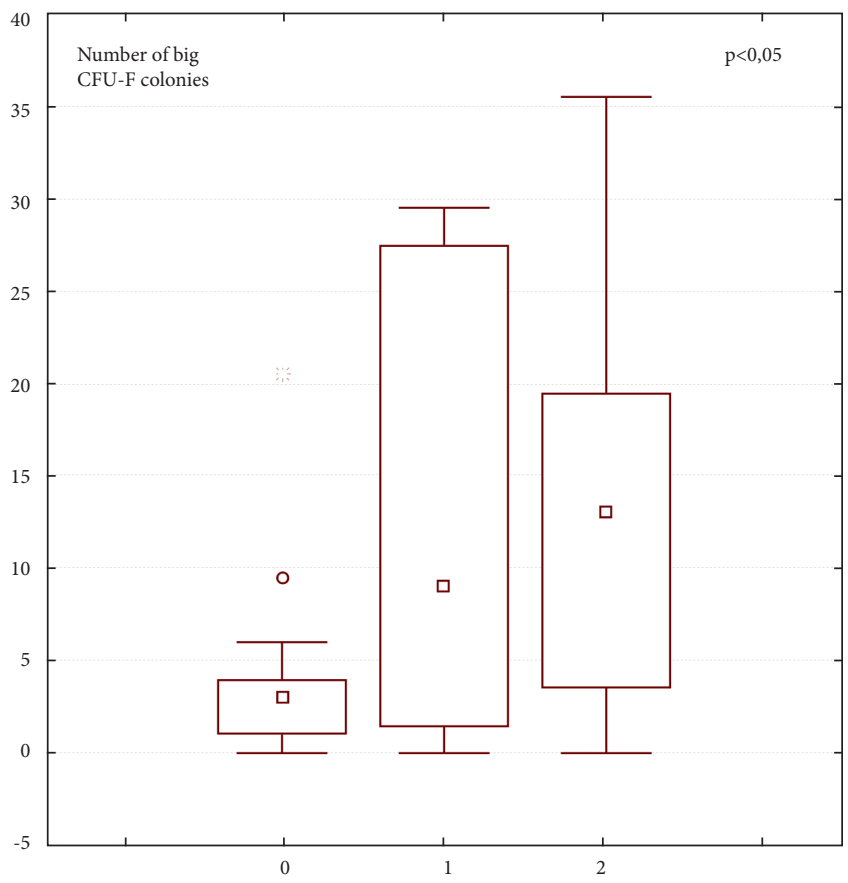

Figure 1. Proliferative characteristics of BMSC in healthy donors (abscissa, 0), patients with AML (abscissa, 1), or ALL (abscissa, 2). Ordinate, numbers of big CFU-F-colonies.

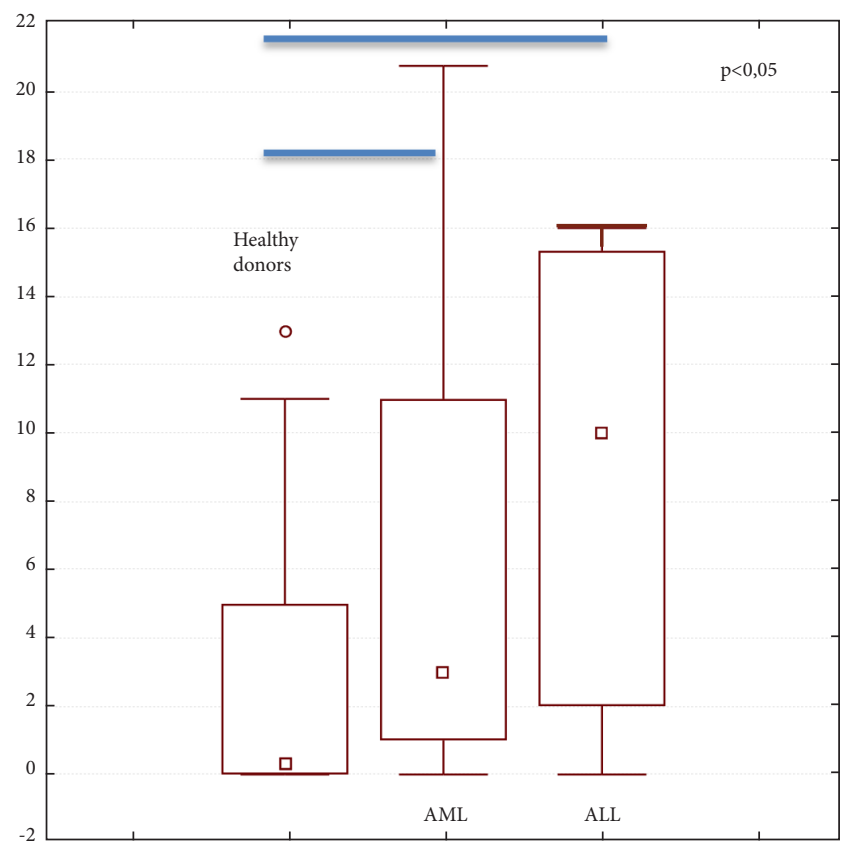

Figure 2. Differentiation ability of BMSC from different sources (abscissa). Ordinate, numbers of osteogenic CFU-F (left); numbers of adipogenic CFU-F (right).

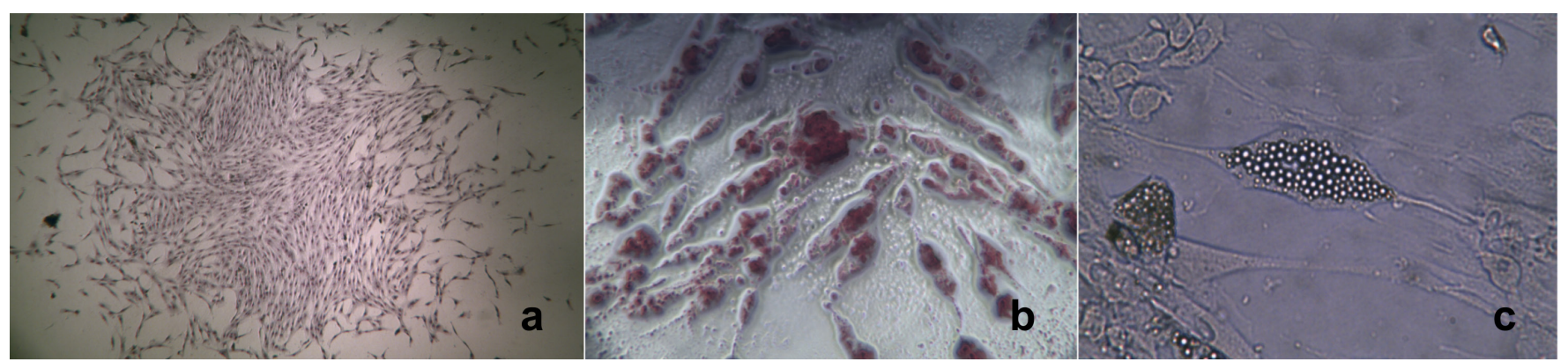

Figure 3. CFU-F, distinct differentiation pathways

a - CFU-F, non-induced. b -CFU-F morphology, osteogenic pattern. Alizarin Red, x100 magnification. c - CFU-F morphology, adipogenic precursors. Sudan Red O Staining, 100x magnification. 
We have also revealed significant differences concerning expression of genes controlling adherence of hematopoietic cells to their substrates in bone marrow. We have found that stromal cells from AL patients exhibited higher expression of SELECTIN and VECAM genes in comparison to BMSC from healthy donors $(\mathrm{p}=0.008$ and $\mathrm{p}=0.04$, respectively, data not shown) in 17 patients with acute leukemia and healthy donors. Noteworthy, similar assays of PECAM and CXCR4 expression levels did not reveal such differences between stromal cells from AL patients and normal donors. However,

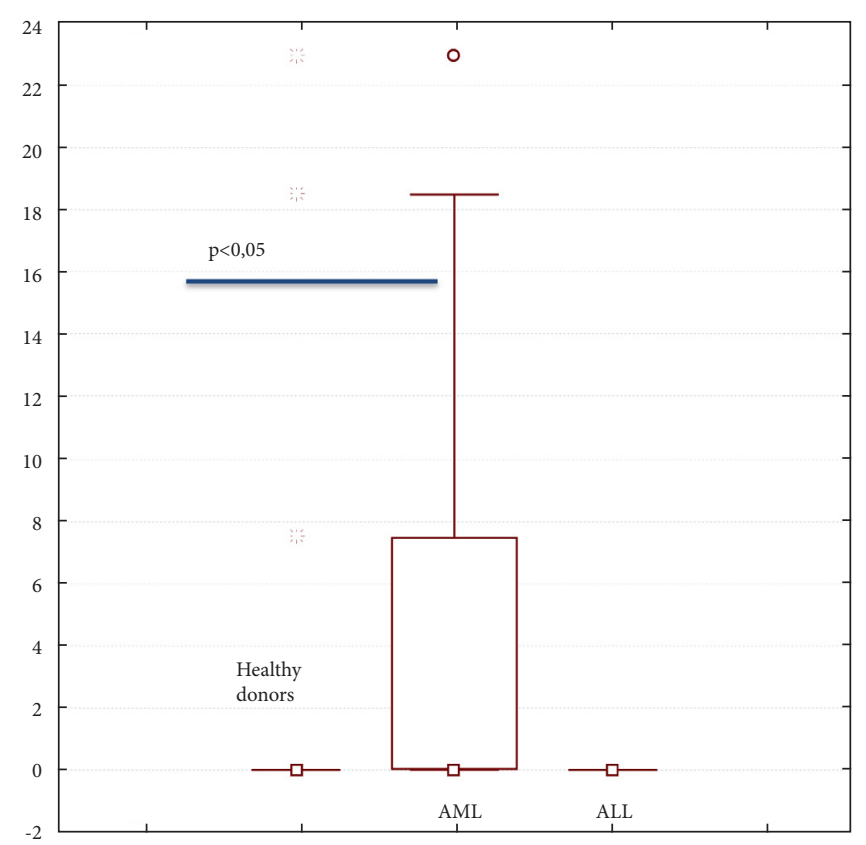

Number of GM-CFU colonies in Agar-drop liquid culture

Figure 4. Hemostimulatory properties of BMCS in agar culture. Ordinate, number of GM-CFU colonies

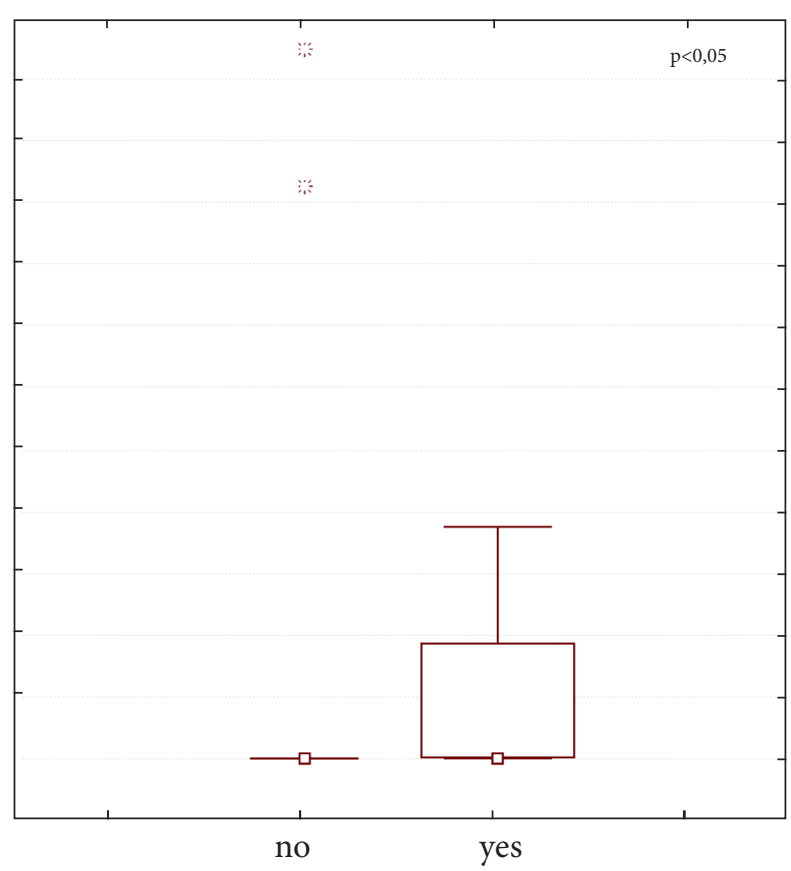

Post transplant relapse we have found a trend for decrease in CXCR4 gene expression among older leukemia patients $(\mathrm{p}=0.05)$. It should be noted that changed expression of adherence factors may be important over post-transplant period since they determine both engraftment kinetics of donor cells and graft functioning at later terms [5].

\section{Role of BMSC supportive characteristics} in hematopoietic engraftment kinetics

When analyzing a potentially predictive role of BMSC functional characteristics for the graft reconstitution, we have revealed a higher in vitro colony-forming ability of recipient BMSCs associated with longer terms of donor cell engraftment. A direct correlation was found between the large and small CFU-F colony numbers and leukocyte recovery terms ( $>1.0$ peripheral leukocytes $/ \mu \mathrm{L}$ ), i.e., $\mathrm{R}=0.34, \mathrm{p}=0.00006$ and $\mathrm{R}=0.23, \mathrm{p}=0.006$, respectively. A similar trend was observed, when assessing connections with blood neutrophil recovery $(\mathrm{R}=0.28, \mathrm{p}=0.001$ and $\mathrm{R}=0.21, \mathrm{p}=0.012$, respectively, for large and small CFU-F colonies, data not shown).

Hence, when detecting in vitro hemostimulating activity of recipient stromal cells in comparison to in vivo hematopoietic recovery, we found a direct correlation be tween the number of CFU-GM colonies in soft agar cultures, and the recovery terms for leukocytes and platelets $(>20 / \mathrm{L}), \mathrm{R}=0.58$ and $\mathrm{R}=0.48$, respectively. Meanwhile, analysis of colony formation in methylcellulose culture has shown an inverse correlation, i.e., shorter engraftment terms for blood leukocytes and platelets, with increasing support of colony-forming ability by stromal BMSCs derived from the recipient. Hence, it may indicate effects of short-distance factors promoting hematopoietic reconstitution after transplantation which may effectively support hematopoiesis in liquid culture but not in soft

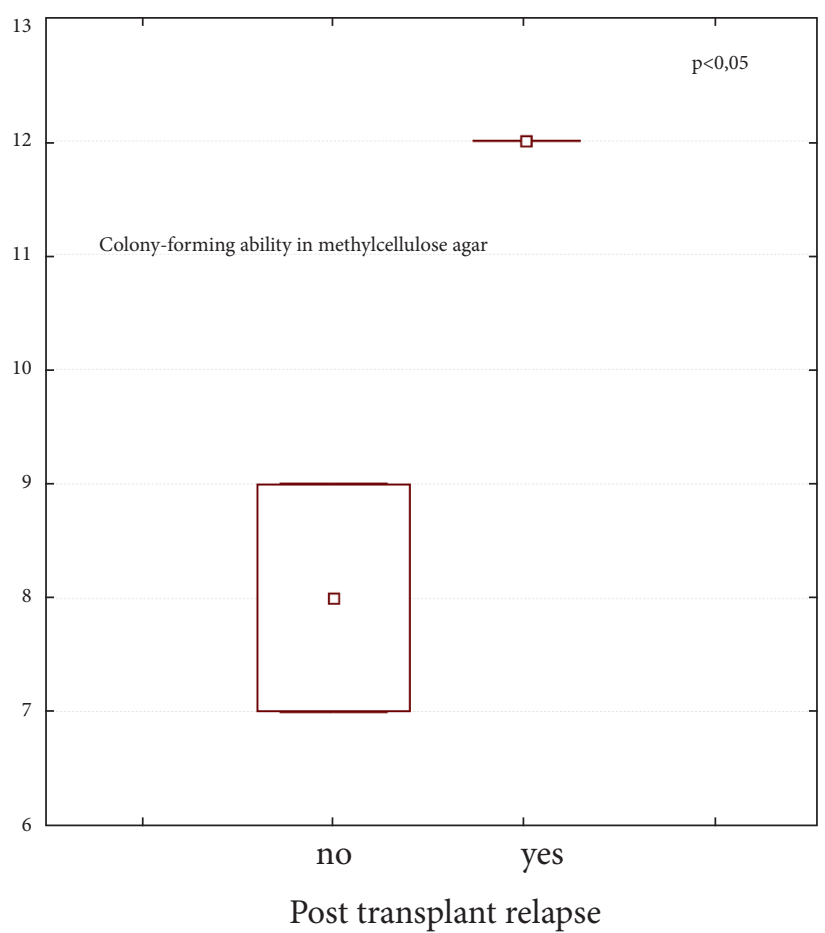

Figure 5. The likelihood of post-transplant relapse depends on the differences of recipient BMSC in vitro haemostimulating activity. Ordinate, CFU numbers in agar culture (left); CFU numbers in methylcellulose culture (right). 
agar. At the same time, while the higher hematopoietic progenitor colony formation in methylcellulose correlated with increased probability of post-transplant relapse $(p<0.05)$. In the culture system "drop-agar liquid medium" such patterns have not been identified (Fig. 5), indicating that the contribution relapse in expectation of the same factors.

Moreover, we studied some relationships between quantitative parameters of osteogenic and adipogenic CFU-F, and the rates of hematopoietic engraftment. We have shown that the recovery time for leukocytes and platelets is reduced in the patients with higher in vitro osteogenic

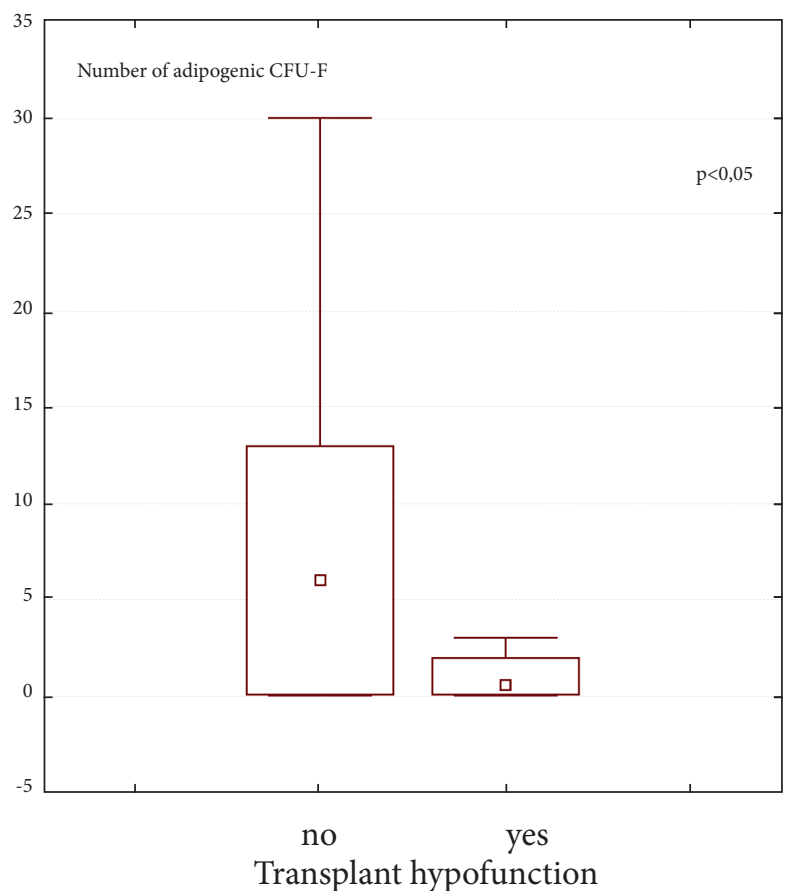

Figure 6. Dependence between the in vitro BMSCs adipogenic differentiation ability and post-transplant graft hypofunction

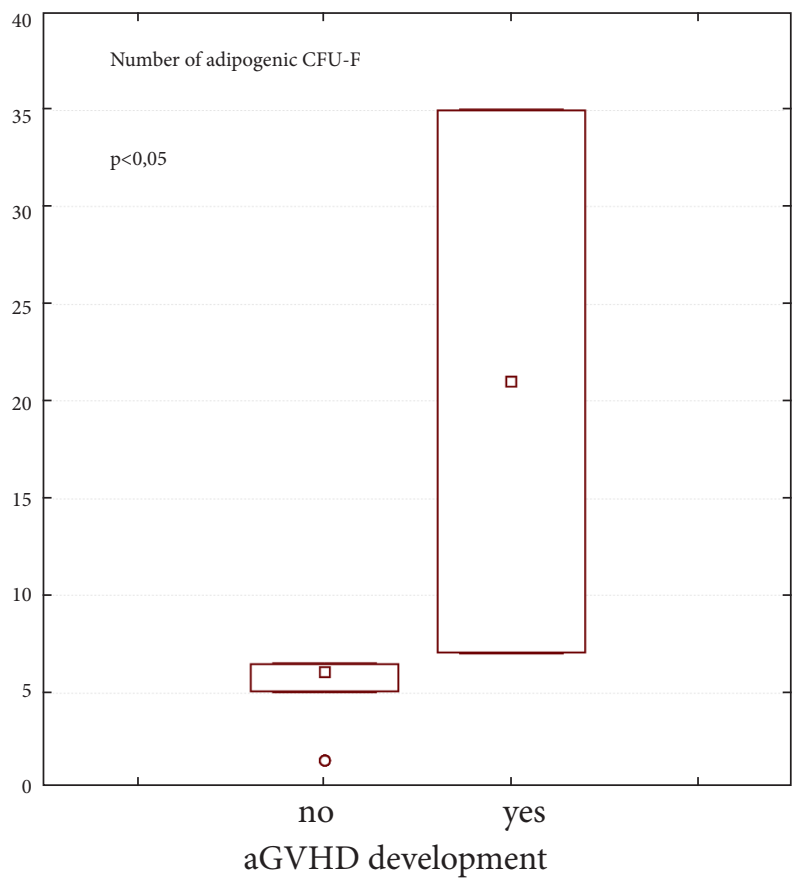

potential of their CFU-F ( $p=0,034)$, as well as a significantly reduced probability of graft hypofunction in cases of a higher number of adipogenic CFU-Fs in recipient stromal populations ( $\mathrm{p}<0.05$ ) (Fig. 6). A number of studies have shown that adipocytes act primarily as a negative regulator of hematopoiesis and are able to lengthen the periods of post-transplant reconstitution of hematopoiesis [12]. In turn, osteoblasts are seen as one of the key components of the hematopoietic microenvironment, regulating adhesion, homing and engraftment of HSCs during post-transplant period. There is the evidence of a leukemic clone inhibition by osteoblasts, thus creating favorable conditions for normal hematopoiesis [8].

When assessing a probability of acute graft-versus-host disease (aGvHD), we have shown that a higher risk of this common HSCT complication was associated with increased proliferative capacity characteristics of the recipient stromal cells, as expressed by CFU-F growth, and higher relative contents of large CFU-F colonies (>100 cells). Interestingly, despite our data, which point to hemostimulating ability of osteoblast progenitors and their role in faster post-transplant recovery, we have not received data which suggest higher risk of relapse in cases of increased osteogenic CFU-F numbers ( $p>0.05$ ) There is also an association between increased numbers of osteogenic CFU-F and risk of aGvHD development ( $p>0.05$ ) (Fig. 7).

Another evidence concerns mRNA expression of adhesion molecules (Selectin, Pecam, VCAM and CXCR4) in BMSCs. We have revealed shorter engraftment terms for leukocytes and platelets in the patients with increased mRNA expression of adhesion molecules in patient BMSC ( $\mathrm{p}<0.05)$ (data not shown). However, the increase of these markers expression was associated with a higher probability of relapse and reduced post-transplant chimerism stability $(\mathrm{p}<0.05)$ (Fig. 8).

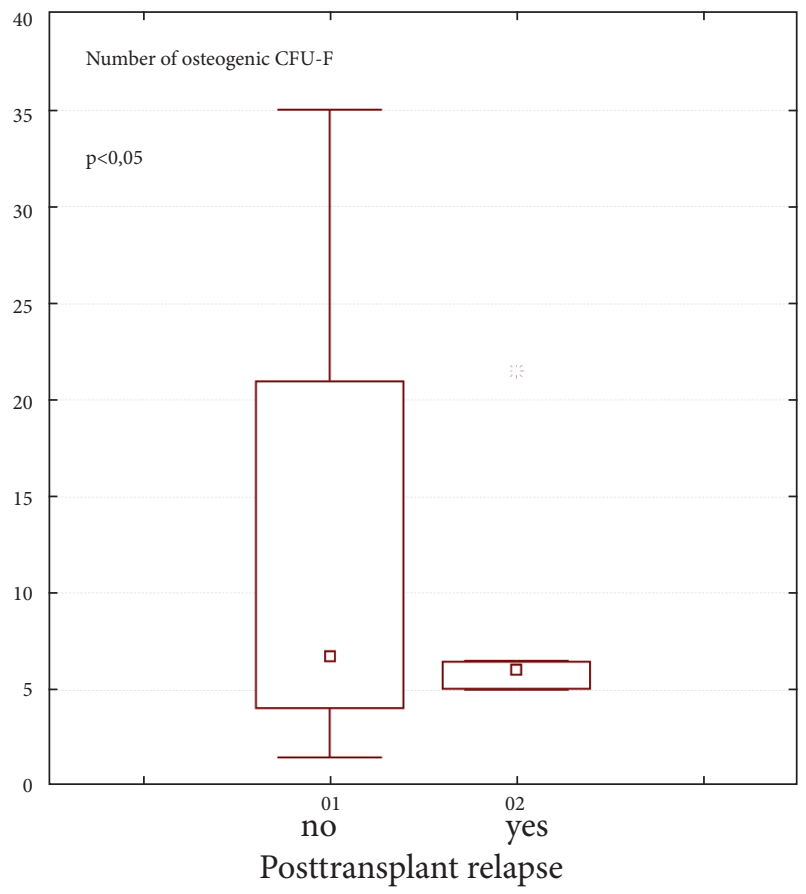

Figure 7. Occurrence of aGvHD (left) and clinical relapse (right) depend on in vitro BMSC osteogenic differentiation ability 

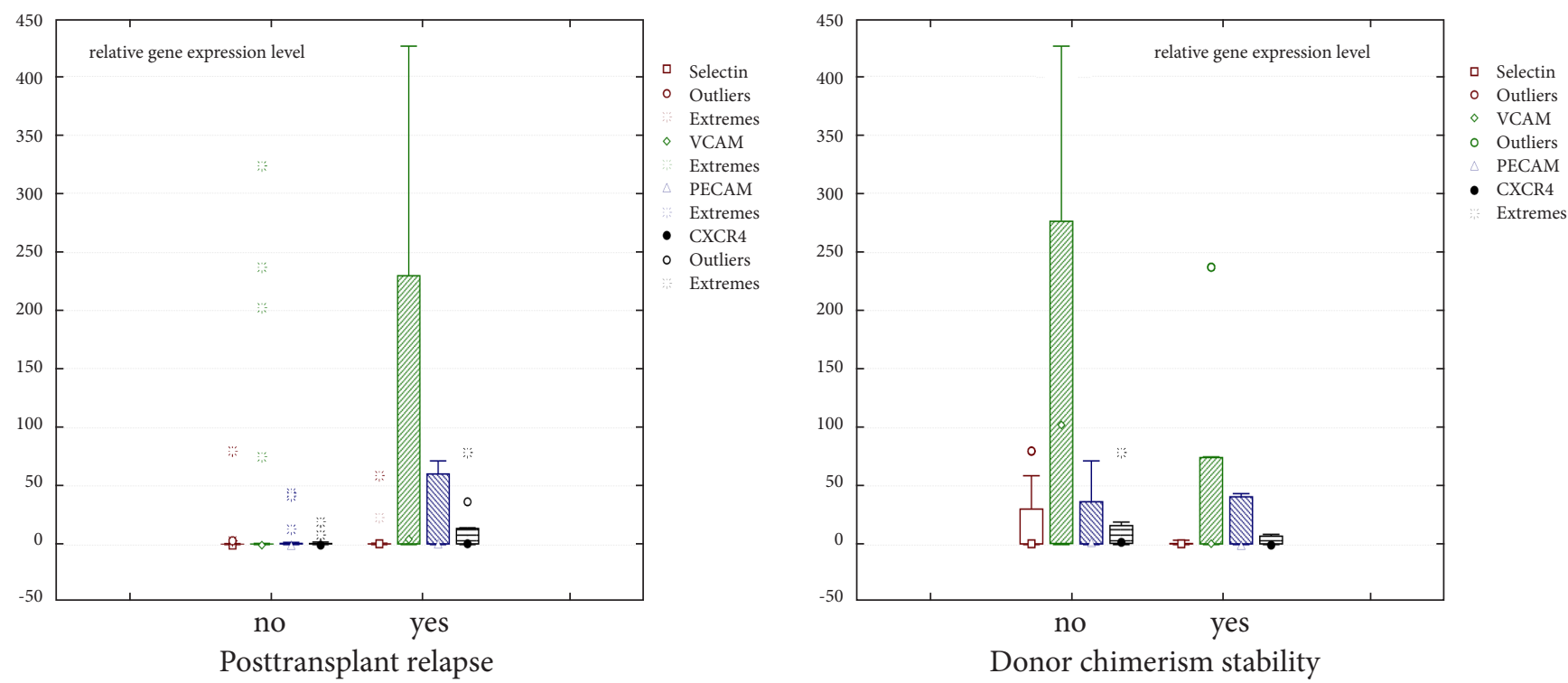

Figure 8. Dependence on post-transplant relapse (left) and stability of donor chimerism (right) on the in vitro mRNA expression of some adhesion molecules in BMSCs

\section{Conclusions}

1. Our findigs indicate the presence of higher proliferative activity and hemostimulating ability of BMSC in acute leukemia patients compared with healthy donors

2. These biological effects of stroma may be ascribed to preceding chemotherapy and myelosuppression which affected stromal cells, or its interaction with the tumor clone. 3. Functional characteristics of patients' stromal cells may influence on posttransplant hematopoiesis recovery. Thus increase of the osteogenic differentiation is associated with a faster recovery of hematopoiesis, whereas adipogenic differentiation is associated with less probability of graft hypofunction. Some short-range haemostimulating factors may be responsible for such effect.

4. Increased pre-transplant expression of some genes controlling HSC-homing molecules in recipient stroma is associated with sooner hematopoietic recovery, however, with higher occurence of post-transplant relapses.

\section{Acknowledgement}

The study was supported by The Russian Foundation for Basic Studies, Grant № 15-04-08679

\section{References}

1. Afanasyev BV, Kulibaba TG, Zabelina TS, Lukasheva TN, Smirnova GA. Agar cloning of hematopoietic cells from the patients with different forms of hematopoietic dysplasia (clinics vs culture). Ter Arkhiv. 1982; 8:97-103.

2. Blau O, Hofmann WK, Baldus CD, Thiel G, Serbent V, Schümann E, Thiel E, Blau IW.. Chromosomal aberrations in bone marrow mesenchymal stroma cells from patients with myelodysplastic syndrome and acute myeloblastic leukemia. Exp Hematol. 2007; 35 (2):221-229.

3. Borojevic R, Roela RA, Rodarte RS, Thiago LS, Pasini FS, Conti FM, Rossi MI, Reis LF, Lopes LF, Brentani MM. Bone marrow stroma in childhood myelodysplastic syndrome:
Composition, ability to sustain hematopoiesis in vitro, and altered gene expression. Leuk Res. 2004; 28 (8):831-844.

4. Calvi LM, Adams GB, Weibrecht KW, Weber JM, Olson DP, Knight MC, Martin RP, Schipani E, Divieti P, Bringhurst FR, Milner LA, Kronenberg HM, Scadden DT. Osteoblastic cells regulate the haematopoietic stem cell niche. Nature. 2003; 425 (6960):841-846.

5. Chamberlain G, Fox J, Ashton B, Middleton J. Concise review: mesenchymal stem cells: their phenotype, differentiation capacity, immunological features, and potential for homing. Stem Cells. 2007; 25 (11):2739-2749.

6. Flores-Figueroa E, Arana-Trejo RM, Gutiérrez-Espíndola G, Pérez-Cabrera A, Mayani H. Mesenchymal stem cells in myelodysplastic syndromes: Phenotypic and cytogenetic characterization. Leuk Res. 2005; 29 (2):215-224.

7. Konopleva M, Tabe Y, Zeng Z, Andreeff M. Therapeutic targeting of microenvironmental interactions in leukemia: Mechanisms and approaches. Drug Resist Updat. 2009; 12 (4-5):103-113.

8. Krevvata M, Silva BC, Manavalan JS, Galan-Diez M, Kode A, Matthews BG, Park D, Zhang CA, Galili N, Nickolas TL, Dempster DW, Dougall WJ T-F. Inhibition of leukemia cell engraftment and disease progression in mice by osteoblasts. Blood. 2014; 124 (18):2834-2846.

9. Le Y, Fraineau S, Chandran P, Sabloff $M$, Brand $M$, Lavoie JR, Gagne R, Rosu-Myles M, Yauk CL, Richardson RB, Allan DS. Adipogenic mesenchymal stromal cells from bone marrow and their hematopoietic supportive role: towards understanding the permissive marrow microenvironment in acute myeloid leukemia. Stem Cell Rev Reports. 2016; 12 (2):235-244.

10. Le Blanc K. Mesenchymal stromal cells: Tissue repair and immune modulation. Cytotherapy. 2006; 8 (6):559-561.

11. Le Blanc K, Samuelsson H, Gustafsson B, Remberger M, Sundberg B, Arvidson J, Ljungman P, Lönnies H, Nava S, 
Ringdén O. Transplantation of mesenchymal stem cells to enhance engraftment of hematopoietic stem cells. Leukemia. 2007; 21 (8):1733-1738.

12. Naveiras O, Nardi V, Wenzel PL, Hauschka PV, Fahey F, Daley GQ. Bone-marrow adipocytes as negative regulators of the haematopoietic microenvironment. Nature. 2009; 460 (7252):259-263.

13. Podar K, Richardson PG, Hideshima T, Chauhan D, Anderson KC. The malignant clone and the bone-marrow environment. Best Pract Res Clin Haematol. 2007; 20 (4):597612.

14. Prockop DJ. Marrow stromal cells as stem cells for nonhematopoietic tissues. Science. 1997;4;276(5309):71-74.

15. Rieger K, Marinets O, Fietz T, Körper S, Sommer D, Mücke C, Reufi B, Blau WI, Thiel E, Knauf WU. Mesenchymal stem cells remain of host origin even a long time after allogeneic peripheral blood stem cell or bone marrow transplantation. Exp Hematol. 2005; 33 (5):605-611.
16. Scadden DT. The stem cell niche in health and leukemic disease. Best Pr Res Clin Haematol. 2007; 20 (1):19-27.

17. Shipounova IN, Petinati NA, Bigildeev AE, Drize NJ, Sorokina TV, Kuzmina LA, Parovichnikova EN, Savchenko VG. Alterations of the bone marrow stromal microenvironment in adult patients with acute myeloid and lymphoblastic leukemias before and after allogeneic hematopoietic stem cell transplantation. Leuk Lymphoma. 2017; 58 (2):408-417.

18. Yang G-C, Xu Y-H, Chen H-X, Wang X-J. Acute Lymphoblastic Leukemia Cells Inhibit the Differentiation of Bone Mesenchymal Stem Cells into Osteoblasts In Vitro by Activating Notch Signaling. Stem Cells Int. 2015; 2015:1-11.

19. Zhang J, Niu C, Ye L, Huang H, He X, Tong WG, Ross J, Haug J, Johnson T, Feng JQ, Harris S, Wiedemann LM, Mishina Y, Li L. Identification of the haematopoietic stem cell niche and control of the niche size. Nature. 2003; 425:836-841.

\title{
Влияние функциональных характеристик стромальных клеток костного мозга реципиента на приживление после алло-ТГСК
}

\author{
Ильдар М. Бархатов, Николай Ю. Цветков, Даниил Е. Ершов, Марина Ю. Лаврухина, Алена И. Шакирова, Алиса Я. \\ Поттер, Анна Г. Смирнова, Людмила С. Зубаровская, Борис В. Афанасьев
}

Первый Санкт-Петербургский государственный медицинский Университет им. акад. И. П. Павлова Министерства Здравоохранения РФ, Санкт-Петербург, Россия

\section{Резюме}

Наблюдаемая в ряде случаев гипофункция трансплантата является нередкой и обусловливает необходимость разработки функциональных тестов исследования клеток стромы с целью обоснования показаний к совместной трансплантации гемопоэтических и стромальных клеток костного мозга. Целью данного исследования являлось изучение роли стромальных клеток костного мозга в процессе приживления донорского костного мозга и их значения в развитии осложнений после ТГСК. При анализе функциональных характеристик стромальных клеток у 38 реципиентов аллогенного трансплантата гемопоэтических стволовых клеток было показано увеличение активности остеогенной дифференцировки на фоне укорочения сроков восстановления кроветворения. Вместе с тем, наличие более выраженной способности к адипогенной дифференцировке ассоциировано с меньшей вероятностью развития гипофункции трансплантата. При исследовании гемостимулирующей активности стромальных клеток реципиента были отмечены факты, указывающие на преимущественное влияние короткодистантных ростовых факторов на посттрансплантационную реконституцию гемопоэза. При этом более выраженная экспрессия молекул, опосредующих хоуминг ГСК в стромальных клетках реципиента перед трансплантацией ассоциировано с более быстрым восстановлением гемопоэза у трансплантированных больных.

\section{Ключевые слова}

Стромальные клетки костного мозга, острые лейкозы, функциональные характеристики, типы дифференцировки. 